\title{
Agglomeration of titanium dioxide nanoparticles increases toxicological responses in vitro and in vivo
}

\author{
Sivakumar Murugadoss ${ }^{1}$, Frederic Brassinne ${ }^{2}$, Noham Sebaihi ${ }^{3}$, Jasmine Petry ${ }^{3}$, Stevan M. Cokic ${ }^{4}$, \\ Kirsten L. Van Landuyt ${ }^{4}$, Lode Godderis ${ }^{5,6}$, Jan Mast ${ }^{2}$, Dominique Lison ${ }^{7}$, Peter H. Hoet ${ }^{1 *}$ (D) and \\ Sybille van den Brule 7* $^{*}$
}

\begin{abstract}
Background: The terms agglomerates and aggregates are frequently used in the regulatory definition(s) of nanomaterials (NMs) and hence attract attention in view of their potential influence on health effects. However, the influence of nanoparticle (NP) agglomeration and aggregation on toxicity is poorly understood although it is strongly believed that smaller the size of the NPs greater the toxicity. A toxicologically relevant definition of NMs is therefore not yet available, which affects not only the risk assessment process but also hinders the regulation of nano-products. In this study, we assessed the influence of NP agglomeration on their toxicity/biological responses in vitro and in vivo.

Results: We tested two $\mathrm{TiO}_{2}$ NPs with different primary sizes (17 and $117 \mathrm{~nm}$ ) and prepared ad-hoc suspensions composed of small or large agglomerates with similar dispersion medium composition. For in vitro testing, human bronchial epithelial (HBE), colon epithelial (Caco2) and monocytic (THP-1) cell lines were exposed to these suspensions for $24 \mathrm{~h}$ and endpoints such as cytotoxicity, total glutathione, epithelial barrier integrity, inflammatory mediators and DNA damage were measured. Large agglomerates of $17 \mathrm{~nm} \mathrm{TiO}_{2}$ induced stronger responses than small agglomerates for glutathione depletion, IL-8 and IL-1 $\beta$ increase, and DNA damage in THP-1, while no effect of agglomeration was observed with $117 \mathrm{~nm} \mathrm{TiO} 2$.

In vivo, C57BL/6JRj mice were exposed via oropharyngeal aspiration or oral gavage to $\mathrm{TiO}_{2}$ suspensions and, after 3 days, biological parameters including cytotoxicity, inflammatory cell recruitment, DNA damage and biopersistence were measured. Mainly, we observed that large agglomerates of $117 \mathrm{~nm} \mathrm{TiO}$ induced higher pulmonary responses in aspirated mice and blood DNA damage in gavaged mice compared to small agglomerates.

Conclusion: Agglomeration of $\mathrm{TiO}_{2} \mathrm{NPs}$ influences their toxicity/biological responses and, large agglomerates do not appear less active than small agglomerates. This study provides a deeper insight on the toxicological relevance of NP agglomerates and contributes to the establishment of a toxicologically relevant definition for NMs.
\end{abstract}

Keywords: Nanomaterials, Titanium dioxide, Agglomerates, Toxicity, Biological responses

\footnotetext{
* Correspondence: peter.hoet@kuleuven.be;

sybille.vandenbrule@uclouvain.be

'Laboratory of Toxicology, Unit of Environment and Health, Department of

Public Health and Primary Care, KU Leuven, 3000 Leuven, Belgium

7Louvain centre for Toxicology and Applied Pharmacology, Institute of

Experimental and Clinical Research, Université catholique de Louvain, 1200

Brussels, Belgium

Full list of author information is available at the end of the article
}

(c) The Author(s). 2020 Open Access This article is distributed under the terms of the Creative Commons Attribution 4.0 International License (http://creativecommons.org/licenses/by/4.0/), which permits unrestricted use, distribution, and

reproduction in any medium, provided you give appropriate credit to the original author(s) and the source, provide a link to the Creative Commons license, and indicate if changes were made. The Creative Commons Public Domain Dedication waiver (http://creativecommons.org/publicdomain/zero/1.0/) applies to the data made available in this article, unless otherwise stated. 


\section{Background}

Manufactured nanomaterials (NMs) exist as unbound (single) particles, agglomerates, aggregates or as a mixture thereof [1-4]. This is clearly recognised in the definition of NMs recommended by the European Union (EU) stating "manufactured material containing particles, in an unbound state or as an aggregate or as an agglomerate and where, for $50 \%$ or more of the particles in the number size distribution, one or more external dimensions is in the size range $\mathbf{1} \mathbf{n m - 1 0 0 ~} \mathbf{n m}$ " [5]. This definition was proposed for legislative and regulatory purposes with no direct regard to hazard. Although agglomerates and aggregates (AA) are often erroneously considered similar and interchangeably used, they are, however, two different secondary structures of particulate materials. In agglomerates, the particles bind together by weak forces, which are reversible, while, in aggregates, particles fuse irreversibly together [6]. The terms AA attracted in recent years attention among the NM producers, consumers, regulatory authorities and policy makers in view of their potential influence on human health effects $[5,7,8]$. However, no sound scientific data justify that AA may or may not be relevant from a toxicological perspective. This knowledge gap is not only affecting the risk assessment process but also hindering the development of guidelines to regulate NMs in commercial products.

Agglomeration in particular, is a ubiquitous phenomenon and its dynamic behaviour poses a great challenge in assessing health impacts $[9,10]$. Unlike aggregates, agglomerates are very sensitive to changes in the environment such as $\mathrm{pH}$, ionic strength, presence of proteins and motion of the carrier medium, and can de-agglomerate/agglomerate further depending on the environment $[10,11]$. While this induces complex behaviour of NMs in exposure scenarios and in tissue uptake and bio-distribution, influence on toxicity/biological responses remain poorly understood $[9,10]$.

Titanium dioxide $\left(\mathrm{TiO}_{2}\right)$ is one of the most abundantly produced NMs and is used in food, paints and in personal care products $[12,13]$. Humans are increasingly exposed to $\mathrm{TiO}_{2}$ via inhalation, dermal or oral exposure. Based on animal studies, the International Agency for Research on Cancer (IARC) classified $\mathrm{TiO}_{2}$ as a group 2B carcinogen (possibly carcinogenic to humans) [14]. Very recently, the French agency for food, environmental and occupational health and safety (ANSES) banned the use of $\mathrm{TiO}_{2}$ as a food additive (E171) due to its genotoxic potential [15]. While several studies showed that $\mathrm{TiO}_{2}$ NPs can induce adverse effects including DNA damage and chromosomal damage, findings are contradictory $[16,17]$. $\mathrm{TiO}_{2}$ NPs are well known for their agglomeration and, so far, extensive efforts have been dedicated at minimizing agglomeration using different dispersion protocols to assess their toxicity despite a lack of evidence that agglomeration influences their toxicity/ biological responses.

In this study, we aimed to determine the influence of agglomeration state of $\mathrm{TiO}_{2}$ NPs on toxicity/biological effects. Toxicological studies generally suggest that the smaller the size of the primary NPs the greater the toxicity/biological responses [18-21]. Therefore, we hypothesized that smaller agglomerates of NPs induce stronger toxicity/biological responses compared to their largely agglomerated counterparts. To test this hypothesis, we selected two $\mathrm{TiO}_{2}$ NPs of identical phase, coating and chemical composition but with different primary particle size and compared their toxicity in different agglomeration states using in vitro and in vivo models.

\section{Results}

Dispersions and size characterization of $\mathrm{TiO}_{2} \mathrm{NP}$ agglomerate suspensions

Our strategy to prepare ad-hoc stable suspensions of $\mathrm{TiO}_{2}$ NPs with different agglomeration states, in the same dispersion medium, was based on the method developed by Guiot and Spalla [22] (illustrated in Additional file 1: Figure S2). Figure 1 shows representative Transmission Electron Microsopy (TEM) micrographs of the freshly prepared $\mathrm{TiO}_{2}$ stock suspensions. The 17 nm sized $\mathrm{TiO}_{2}$ at $\mathrm{pH} 2$ was relatively well dispersed and predominantly existed as small aggregates (indicated as $\mathbf{1 7} \mathbf{n m}-\mathbf{S A}$ ) compared to the suspension prepared at $\mathrm{pH}$ 7.5, in which particles tend to agglomerate strongly (17 nm-LA). In contrast, $117 \mathrm{~nm} \mathrm{TiO}_{2}$ were found to be less agglomerated when dispersed at $\mathrm{pH} 7.5$ (117 nm-SA) and existed as large agglomerates when dispersed at $\mathrm{pH}$ 2 solution (117 $\mathbf{~ m m - L A ) . ~ A f t e r ~ d i s p e r s i o n ~ i n ~ t h e ~ r e s p e c t - ~}$ ive $\mathrm{pH}$ conditions, $\mathrm{TiO}_{2}$ suspensions were sonicated at constant energy (7056 J) and stabilized immediately using bovine serum albumin (BSA, 0.25\%). The suspensions dispersed at $\mathrm{pH} 2$ were readjusted to $\mathrm{pH} 7-7.5$ before size characterization and cell/animal exposure.

Sizes of $\mathrm{TiO}_{2}$ suspensions are presented in Table 1. TEM analyses showed that the median Equivalent Circle Diameter (ECD) of $17 \mathrm{~nm}-\mathrm{SA}$ and $117 \mathrm{~nm}-\mathrm{SA}$ were 18 and $122 \mathrm{~nm}$, respectively. The $\mathrm{TiO}_{2}$ NPs were, thus, in their most dispersed state in these suspensions. Median ECD of the large agglomerates, $17 \mathrm{~nm}-\mathrm{LA}$ and $117 \mathrm{~nm}$ LA, were 127 and $352 \mathrm{~nm}$ respectively, clearly indicating that NPs were more agglomerated in these suspensions. Mean ECD were substantially different: $100 \mathrm{~nm}$ for 17 $\mathrm{nm}-\mathrm{SA} ; 200 \mathrm{~nm}$ for $117 \mathrm{~nm}-\mathrm{SA} ; 250 \mathrm{~nm}$ for $17 \mathrm{~nm}-\mathrm{LA}$; and $500 \mathrm{~nm}$ for $117 \mathrm{~nm}$-LA, confirming the overestimation of sizes when means are used. TEM was also applied to measure mean Feret minimum (Feret min) and the measured sizes were slightly different compared to median ECD (Table 1). The mean hydrodynamic diameter 
A

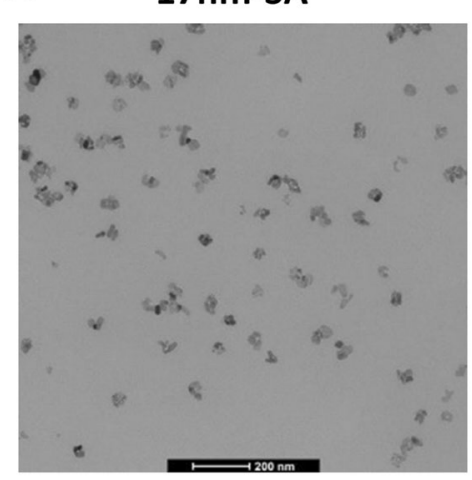

C

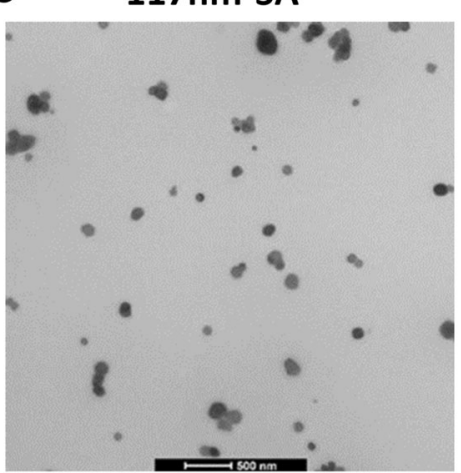

B

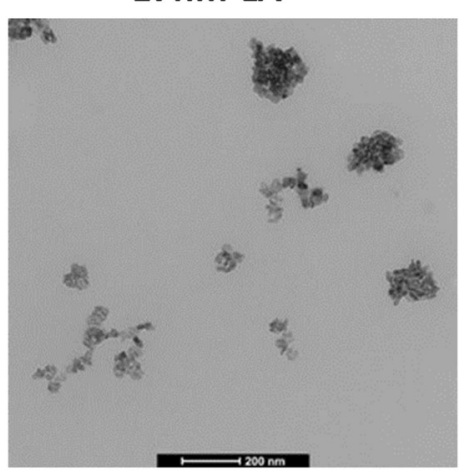

D $\quad 117 n m-$ LA

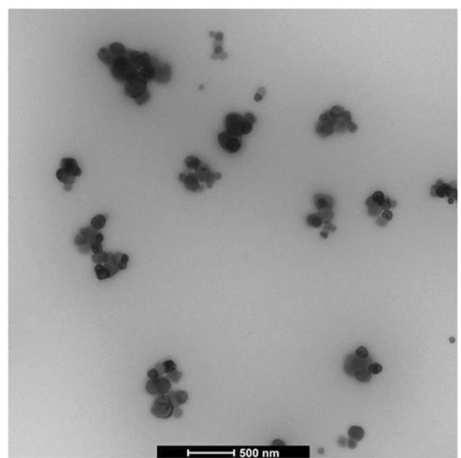

Fig. 1 Representative TEM micrographs of freshly prepared $\mathrm{TiO}_{2}$ stock suspensions of small (SA) and large agglomerates (LA). $17 \mathrm{~nm}$-SA (a), 17 $\mathrm{nm}-\mathrm{LA}(\mathbf{b}), 117 \mathrm{~nm}-\mathrm{SA}(\mathbf{c})$ and $117 \mathrm{~nm}-\mathrm{LA}(\mathbf{d})$

(Z-average) measured by dynamic light scattering (DLS) showed larger sizes for $17 \mathrm{~nm} \mathrm{TiO}_{2}$ (SA $600 \mathrm{~nm}$; LA 900 $\mathrm{nm}$ ) than $117 \mathrm{~nm}$ stock suspensions (SA $280 \mathrm{~nm}$; LA 580 $\mathrm{nm})$. Hydrodynamic sizes measured using particle tracking analysis (PTA) were smaller than Z-average in sizes for 17 nm $\mathrm{TiO}_{2}$ suspensions (SA 134 and LA $207 \mathrm{~nm}$ ) and 117 nm $\mathrm{TiO}_{2}$ suspensions (SA 259 and LA $221 \mathrm{~nm}$ ).

The stability of these suspensions in exposure media was measured by DLS (Table 2). After dilution to $100 \mu \mathrm{g} / \mathrm{mL}$, Z-averages were measured directly and after $24 \mathrm{~h}$. In DMEM/F12 (typically used for HBE cell cultures) and RPMI 1640 (used for THP-1) only a slight change was observed after $24 \mathrm{~h}$ of incubation. In DMEM/HG (used for Caco2), at least a two-fold increase of Z-average after $24 \mathrm{~h}$ incubation was noted. The polydispersity index (PDI) was less than $\sim 0.35$ in stock suspensions and in cell culture medium at 0 and $24 \mathrm{~h}$, indicating an acceptable distribution of sizes and good stability of these suspensions.

In conclusion, TEM indicated a clear difference between SA and LA for both $\mathrm{TiO}_{2}$ NPs and stock suspensions were found to be stable over $24 \mathrm{~h}$ using DLS, indicating that these ad-hoc suspensions were appropriate to test our hypothesis.

Table 1 Size characterization of freshly prepared $\mathrm{TiO}_{2}$ stock suspensions $(2.56 \mathrm{mg} / \mathrm{mL})$

\begin{tabular}{|c|c|c|c|c|c|}
\hline \multirow{2}{*}{$\begin{array}{l}\text { Stock } \\
\text { suspensions }\end{array}$} & \multicolumn{3}{|l|}{ TEM } & \multirow{2}{*}{$\begin{array}{l}\text { DLS } \\
\text { Z-average }(\mathrm{nm})\end{array}$} & \multirow{2}{*}{$\begin{array}{l}\text { PTA } \\
\text { Mean hydrodynamic size }(\mathrm{nm})\end{array}$} \\
\hline & $\begin{array}{l}\text { Median } \\
\mathrm{ECD}(\mathrm{nm})\end{array}$ & $\begin{array}{l}\text { Mean } \\
\text { ECD }(n m)\end{array}$ & $\begin{array}{l}\text { Mean } \\
\text { Feret } \min (\mathrm{nm}) \pm \mathrm{SD}\end{array}$ & & \\
\hline $17 \mathrm{~nm}-\mathrm{SA}$ & 18 & 100 & $33 \pm 2$ & 600 & 134 \\
\hline $17 \mathrm{~nm}-\mathrm{LA}$ & 127 & 200 & $120 \pm 19$ & 900 & 207 \\
\hline $117 \mathrm{~nm}-\mathrm{SA}$ & 122 & 250 & $148 \pm 10$ & 280 & 259 \\
\hline $117 \mathrm{~nm}-\mathrm{LA}$ & 352 & 500 & $309 \pm 64$ & 580 & 221 \\
\hline
\end{tabular}

Median and mean equivalent circle diameter (ECD) and mean feret minimum (feret min) measured by transmission electron microscopy (TEM), Z-average (mean hydrodynamic size) by dynamic light scattering (DLS) and mean hydrodynamic size by particle tracking analysis (PTA) 
Table 2 Size characterization of $\mathrm{TiO}_{2}$ in stock and exposure media (HBE,Caco2 and THP-1) using DLS

\begin{tabular}{|c|c|c|c|c|c|c|c|c|c|}
\hline & & \multicolumn{2}{|l|}{ Stock } & \multicolumn{2}{|c|}{$\begin{array}{l}\text { DMEM/F12 } \\
\text { (HBE) }\end{array}$} & \multicolumn{2}{|c|}{$\begin{array}{l}\text { DMEM/HG } \\
(\text { (Caco2) }\end{array}$} & \multicolumn{2}{|c|}{$\begin{array}{l}\text { RPMI } 1640 \\
(\text { THP-1) }\end{array}$} \\
\hline & & Z-avg & PDI & Z-avg & PDI & Z-avg & PDI & Z-avg & PDI \\
\hline \multirow[t]{2}{*}{$17 \mathrm{~nm}-\mathrm{SA}$} & $\mathrm{Oh}$ & 600 & 0.34 & 670 & 0.27 & 630 & 0.31 & 1140 & \\
\hline & $24 \mathrm{~h}$ & 600 & 0.35 & 850 & 0.24 & 1580 & 0.28 & 1035 & \\
\hline \multirow[t]{2}{*}{$17 \mathrm{~nm}-\mathrm{LA}$} & $\mathrm{Oh}$ & 900 & 0.42 & 900 & 0.27 & 870 & 0.30 & 1350 & \\
\hline & $24 \mathrm{~h}$ & 800 & 0.40 & 980 & 0.20 & 1546 & 0.24 & 1330 & \\
\hline \multirow[t]{2}{*}{$117 \mathrm{~nm}-\mathrm{SA}$} & $\mathrm{Oh}$ & 280 & 0.18 & 690 & 0.19 & 547 & 0.18 & 1010 & \\
\hline & $24 \mathrm{~h}$ & 290 & 9 & 750 & 0.20 & 1145 & 0.40 & 900 & \\
\hline \multirow[t]{2}{*}{$117 \mathrm{~nm}-\mathrm{LA}$} & $\mathrm{Oh}$ & 580 & 0.36 & 630 & 0.26 & 630 & 0.26 & 880 & \\
\hline & $24 \mathrm{~h}$ & 590 & 0.37 & 650 & 0.21 & 1300 & 0.57 & 960 & \\
\hline
\end{tabular}

Stock suspensions $(2.56 \mathrm{mg} / \mathrm{mL}$ ) were diluted to $100 \mu \mathrm{g} / \mathrm{mL}$ in different cell culture medium and, hydrodynamic sizes (Z-avg) and poly dispersity index (PDI) were measured directly and after $24 \mathrm{~h}$

Influence of $\mathrm{TiO}_{2}$ agglomeration on in vitro dosimetry Before examining biological responses to these differently agglomerated suspensions, we considered the possible influence of differential sedimentation of the suspensions in vitro, which might confound the cell responses. In vitro dosimetry simulation was performed only using DMEM/ F12 (used for HBE) and RPMI 1640 (used for THP-1) because DMEM/HG (used for Caco2) promoted further agglomeration over $24 \mathrm{~h}$ incubation. The main parameters used to perform dosimetry simulation are listed in Additional file 1: Table S1. Figure 2 shows the estimated $\mathrm{TiO}_{2}$ dose reaching the bottom of the wells as a function of nominal (applied) dose. Regardless of the type of exposure medium and $\mathrm{TiO}_{2}$ primary size/agglomeration state, nearly $56-58 \%$ of the applied doses was delivered to the bottom of the wells after $24 \mathrm{~h}$. Thus, the delivered doses between SA and their LA suspensions of both $\mathrm{TiO}_{2}$ did not differ substantially. The results are, therefore, presented as a function of nominal doses (expressed in $\mu \mathrm{g} / \mathrm{mL}$ ).

\section{Comparison of biological responses}

Since inhalation and ingestion are the primary routes of exposure to these NPs during production and use, we studied the in vitro effects in human bronchial (HBE) and colon (Caco2) epithelial cell lines, respectively. In addition, we used a human monocytic cell line (THP-1)

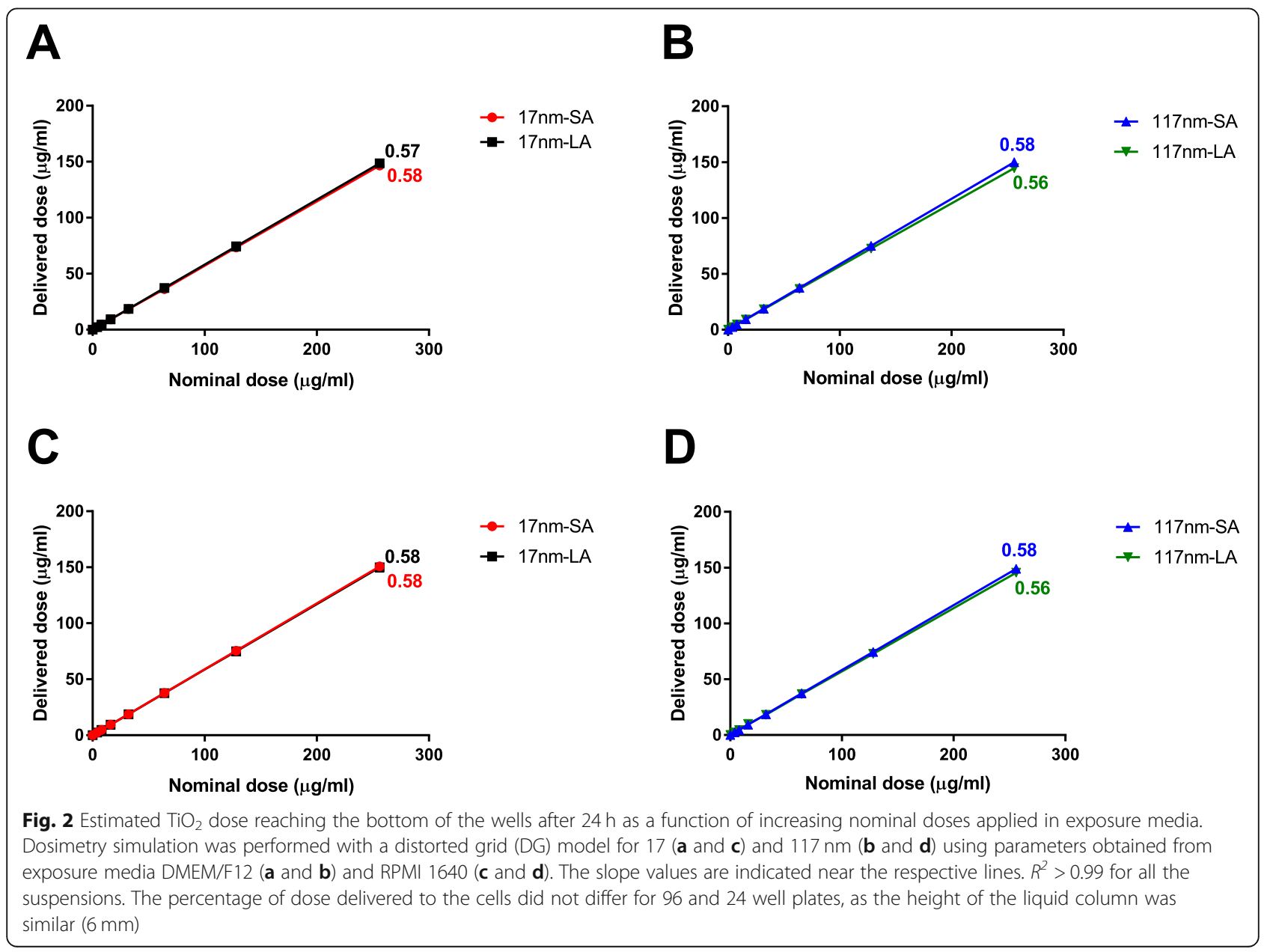


as a representative of innate immune cells that are actively involved in phagocytosis of these particles. To investigate the acute toxicity in vivo, oropharyngeal and gavage administrations were used as representative for inhalation and ingestion, respectively.

In order to investigate the validity of our hypothesis, we first determined the endpoints for which responses to $\mathrm{TiO}_{2}$ exposure (for both SA and LA suspensions) were statistically different compared to untreated control using one-way ANOVA. Table $3 \mathrm{~A}$ and $\mathrm{B}$ summarise these results in vitro and in vivo, respectively. If no impact of $\mathrm{TiO}_{2}$ treatment on a given endpoint in both agglomeration states (SA and LA) was revealed, such endpoint was not used to test the hypothesis of the influence of agglomerations. In a second step, we analysed only those endpoints where $\mathrm{TiO}_{2}$ induced a significant effect at least in one of the agglomeration states (SA or LA). We compared the effects induced by SA and LA using two-way ANOVA. If differences were observed between suspensions, a post hoc test (Bonferroni's multiple comparison test) was used to determine the suspension that induces the strongest effect at the same mass concentration/dose (see Table 4A and B).

The results indicated in green (SA = LA) are shown in Additional file 1: Figures S3 to S8. Significant results indicated in red or blue in Table 4, are presented in Fig. 3 for the in vitro experiments (total glutathione, IL-8, IL$1 \beta$ and DNA damage in THP- 1 exposed to $17 \mathrm{~nm} \mathrm{TiO}{ }_{2}$ ) and in Fig. 4 for the in vivo experiments (lymphocytes in the broncho-alveolar lavage and $\mathrm{Ti}$ persistence in lung tissue for aspirated mice with $117 \mathrm{~nm} \mathrm{TiO}_{2}$, Fig. 4a and b; blood DNA damage in gavaged mice for 17 and 117 $\mathrm{nm} \mathrm{TiO}_{2}$, Fig. 4c and d).

In $\mathrm{HBE}$ and $\mathrm{Caco} 2$ cells, the biological effects, including DNA damage, of SA and LA for both $\mathrm{TiO}_{2}$ samples did not vary (see Additional file 1: Figures S3-S7). In contrast, in THP-1, LA of $17 \mathrm{~nm} \mathrm{TiO}_{2}$ induced stronger GSH depletion, secretion of IL- 8 and IL- $1 \beta$ and more DNA strand breaks compared to SA (Fig. 3). Such differences between SA and LA were not observed for the $117 \mathrm{~nm} \mathrm{TiO}_{2}$ NPs in THP-1 cells. In vivo, LA of $117 \mathrm{~nm}$ $\mathrm{TiO}_{2}$ induced a significantly stronger increase of BAL lymphocytes than SA (Fig. 4a). Further, Ti detected in the lung after $3 \mathrm{~d}$ was significantly higher for LA of 117 nm $\mathrm{TiO}_{2}$ (Fig. 4b). Such differences between SA and LA were not noticed in mice exposed with $17 \mathrm{~nm} \mathrm{TiO}_{2}$ (see Additional file 1: Figure S8A and S8B). In gavaged mice, SA of $17 \mathrm{~nm} \mathrm{TiO}$ and LA of $117 \mathrm{~nm} \mathrm{TiO}$ induced significantly higher blood DNA damage compared to their counterparts (Fig. 4c and d).

\section{Discussion}

The focus of this study was to compare the magnitude of the toxicity/biological responses induced by small
Table 3 Summary of the in vitro (A) and in vivo (B) responses to $\mathrm{TiO}_{2}$ exposure

\begin{tabular}{|c|c|c|c|c|c|c|}
\hline \multicolumn{7}{|l|}{ (A) } \\
\hline \multicolumn{7}{|c|}{ In vitro responses to $\mathrm{TiO}_{2}$ exposure } \\
\hline \multirow[t]{2}{*}{ Biological endpoint } & \multicolumn{2}{|l|}{ HBE } & \multicolumn{2}{|c|}{$\mathrm{Caco} 2$} & \multicolumn{2}{|c|}{ THP-1 } \\
\hline & $\begin{array}{l}17 \\
\mathrm{~nm}\end{array}$ & $\begin{array}{l}117 \\
\mathrm{~nm}\end{array}$ & $\begin{array}{l}17 \\
\mathrm{~nm}\end{array}$ & $\begin{array}{l}117 \\
\mathrm{~nm}\end{array}$ & $\begin{array}{l}17 \\
\mathrm{~nm}\end{array}$ & $\begin{array}{l}117 \\
\mathrm{~nm}\end{array}$ \\
\hline $\begin{array}{l}\text { Cell metabolic } \\
\text { activity }\end{array}$ & No & No & No & No & No & No \\
\hline Cell viability & No & No & No & No & No & No \\
\hline DNA damage & Yes & Yes & Yes & Yes & Yes & Yes \\
\hline GSH & Yes & Yes & Yes & No & Yes & No \\
\hline TEER & Yes & Yes & No & Yes & $\mathrm{n} / \mathrm{a}$ & $\mathrm{n} / \mathrm{a}$ \\
\hline IL-8 & No & No & No & No & Yes & No \\
\hline IL-6 & Yes & No & No & No & No & No \\
\hline TNF-a & No & No & No & No & Yes & No \\
\hline $\mid L-1 \beta$ & No & Yes & No & No & Yes & No \\
\hline
\end{tabular}

(B)

In vivo responses to $\mathrm{TiO}_{2}$ exposure

Biological endpoint Aspiration

Gavage

$\begin{array}{llll}17 & 117 & 17 & 117\end{array}$

BAL cell number No No n/a n/a

BALFLDH No Yes n/a n/a

BALF proteins No No n/a n/a

BAL macrophages No No n/a n/a

BAL neutrophils No No n/a n/a

BAL lymphocytes Yes Yes n/a n/a

Blood lymphocytes No No No No

Blood monocytes No No No No

Blood granulocytes No No No No

Lung $\mathrm{Ti} \quad$ Yes Yes n/a n/a

Blood $\mathrm{Ti}$ No No No No

BAL DNA damage No No n/a n/a

Blood DNA damage n/a n/a Yes Yes

GSH lung No No n/a n/a

GSH liver n/a n/a No No

"Yes" indicates $p<0.05$ (One-way ANOVA) and a significant difference compared to control; "No" indicates $p>0.05$; n/a-not available

(SA) and large agglomerates (LA) of two $\mathrm{TiO}_{2}$ NPs with different primary particle sizes. In in vitro testing, differential responses were observed only in THP-1 cells, where $\mathrm{LA}$ of $17 \mathrm{~nm} \mathrm{TiO}_{2}$ induced stronger biological responses than SA. In in vivo testing, LA of $117 \mathrm{~nm} \mathrm{TiO}_{2}$ induced stronger pulmonary effects and blood DNA damage compared to the SA. These results contradict our initial hypothesis as small $\mathrm{TiO}_{2}$ agglomerates did not necessarily appear more toxic/biologically active than their large counterparts. 
Table 4 Summary of in vitro (A) and in vivo (B) responses to differently agglomerated $\mathrm{TiO}_{2}$ suspensions

\section{$(4 \mathrm{~A})$}

\begin{tabular}{|c|c|c|c|c|c|c|}
\hline \multicolumn{5}{|c|}{ Small agglomerates (SA) vs large agglomerates (LA) } \\
\hline \multirow{2}{*}{$\begin{array}{l}\text { Biological } \\
\text { endpoint }\end{array}$} & \multicolumn{2}{|c|}{ HBE } & \multicolumn{2}{c|}{ Caco2 } & \multicolumn{2}{c|}{ THP-1 } \\
\cline { 2 - 7 } & $17 \mathrm{~nm}$ & $117 \mathrm{~nm}$ & $17 \mathrm{~nm}$ & $117 \mathrm{~nm}$ & $17 \mathrm{~nm}$ & $117 \mathrm{~nm}$ \\
\hline Total GSH & SA=LA & SA=LA & SA=LA & nc & LA>SA & nc \\
\hline TEER & SA=LA & SA=LA & nc & SA=LA & n/a & nc \\
\hline IL-8 & nc & nc & nc & nc & LA>SA & nc \\
\hline IL-6 & SA=LA & nc & nc & nc & nc & nc \\
\hline TNF- $\alpha$ & nc & nc & nc & nc & SA=LA & nc \\
\hline IL-1 $\beta$ & nc & SA=LA & nc & nc & LA $>S A$ & $n c$ \\
\hline DNA damage & SA=LA & SA=LA & SA=LA & SA=LA & LA $>S A$ & SA=LA \\
\hline
\end{tabular}

\section{(4B)}

\begin{tabular}{|c|c|c|c|c|}
\hline \multicolumn{3}{|c|}{ Small agglomerates (SA) vs large agglomerates (LA) } \\
\hline \multirow{2}{*}{$\begin{array}{c}\text { Biological } \\
\text { endpoint }\end{array}$} & \multicolumn{2}{|c|}{ Aspiration } & \multicolumn{2}{c|}{ Gavage } \\
\cline { 2 - 5 } & $17 \mathrm{~nm}$ & $117 \mathrm{~nm}$ & $17 \mathrm{~nm}$ & $117 \mathrm{~nm}$ \\
\hline BALF LDH & $\mathrm{nc}$ & $\mathrm{SA}=\mathrm{LA}$ & $\mathrm{n} / \mathrm{a}$ & $\mathrm{n} / \mathrm{a}$ \\
\hline BALF proteins & $\mathrm{nc}$ & $\mathrm{nc}$ & $\mathrm{n} / \mathrm{a}$ & $\mathrm{n} / \mathrm{a}$ \\
\hline BAL lymphocytes & $\mathrm{SA}=\mathrm{LA}$ & $\mathrm{LA}>\mathrm{SA}$ & $\mathrm{n} / \mathrm{a}$ & $\mathrm{n} / \mathrm{a}$ \\
\hline Ti persistence in lung & $\mathrm{SA}=\mathrm{LA}$ & $\mathrm{LA}>\mathrm{SA}$ & $\mathrm{n} / \mathrm{a}$ & $\mathrm{n} / \mathrm{a}$ \\
\hline Blood DNA damage & $\mathrm{nc}$ & $\mathrm{nc}$ & $\mathrm{SA}>\mathrm{LA}$ & $\mathrm{LA}>\mathrm{SA}$ \\
\hline
\end{tabular}

$\mathrm{SA}=\mathrm{LA}$ (indicated in green) when $p>0.05$; LA $>\mathrm{SA}$ (red) or SA $>$ LA (blue) when $p<0.05$ (Two-way ANOVA). When suspensions are statistically different, a post hoc - Bonferroni's multiple comparison test was used to statistically determine whether LA or SA induced a stronger effect at the same mass concentrations/ doses; nc- not compared as both suspensions did not induce any significant activity compared to control. n/a-not available

To systematically determine the influence of NP agglomeration on toxicity, the thorny task was to develop standardized protocols to reproducibly generate agglomeration. Most importantly, this had to be done with min$\mathrm{imal} /$ negligible variation in the dispersion media, to avoid bias due to medium effects. In the past, some attempts were made to determine the influence of $\mathrm{TiO}_{2} \mathrm{NP}$ agglomeration on toxicity using different protocols. Magdolenova et al. 2012 [23] prepared two suspensions; a welldispersed condition of $\mathrm{TiO}_{2} \mathrm{NPs}$ in the presence of serum proteins $(20 \% \mathrm{FBS})$ and an unstable/agglomerated condition without serum proteins and found that the large agglomerates induced DNA damage in three different cell lines while the small agglomerates did not. Prasad et al. 2013 [24] investigated the effect of three different culture media (with variable amount of BSA and FBS) on agglomeration and observed that $\mathrm{TiO}_{2}$ induced micronuclei in its least agglomerated condition. Lankoff et al. 2012 [25] also used BSA (15\%) and FBS (10\%) and obtained two suspensions with differently agglomerated state, but, in contrast to the two above mentioned studies, these authors did not observe any differences in A549 cell death between the two suspensions. Thus, within the same study, different media and protein concentrations were used to produce suspensions with different states of agglomeration, which is an evident source of potential bias [26] and probably, influenced the toxicological outcome. Therefore, in our study, we decided to vary only the $\mathrm{pH}$ of the initial dispersion medium to modify the agglomeration state of the $\mathrm{TiO}_{2}$ NPs. After stabilization of these dispersions with 


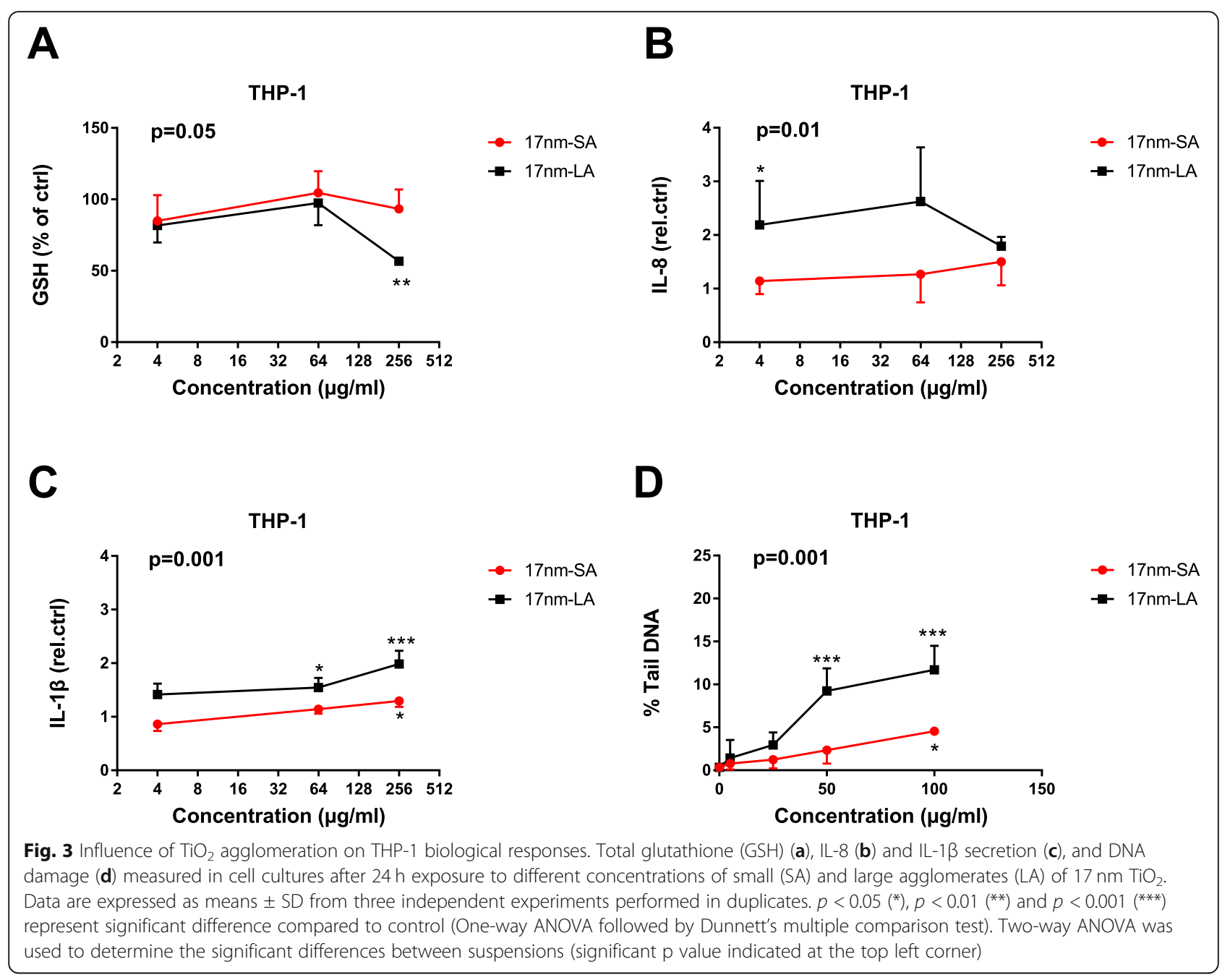

$\mathrm{BSA}$, the $\mathrm{pH}$ was readjusted to obtain a $\mathrm{pH}$ compatible with toxicological tests. At the same $\mathrm{pH}, 17$ and $117 \mathrm{~nm}$ $\mathrm{TiO}_{2}$ existed in different agglomeration state because the isoelectric point of $\mathrm{TiO}_{2} \mathrm{NPs}$ varies according to primary size [27]. Thus, we succeeded to produce $\mathrm{TiO}_{2} \mathrm{NPs}$ in different agglomeration states suitable for testing our hypothesis without experimental bias. Most importantly, we used exactly the same amount of sonication energy (7056 J) and proteins (final BSA concentration, 0.25\%) to disperse and sterically stabilize the differently agglomerated suspensions. To the best of our knowledge, this is the first attempt to produce different agglomeration states of $\mathrm{TiO}_{2}$ NPs with minimal changes in dispersion media, and thus a more reliable approach to study the influence of agglomeration on toxicity.

To characterize the cytotoxic activity of these suspensions in vitro, we investigated the effect on the cell metabolic activity and viability after $24 \mathrm{~h}$ exposure. Both $\mathrm{TiO}_{2}$ NPs were not cytotoxic even in their most dispersed state. Then we compared the potential of SA and LA to induce an oxidative stress, pro-inflammatory responses and DNA damage, or to disturb the epithelial barrier integrity. The agglomeration state of both $\mathrm{TiO}_{2}$ did not influence these responses in $\mathrm{HBE}$ and $\mathrm{Caco} 2$ cell cultures. In contrast to these cell lines, a distinct response was noticed in THP-1 cells, where LA of $17 \mathrm{~nm} \mathrm{TiO}_{2}$ were more potent than SA. Contrary to HBE and Caco2, THP-1 are phagocytic cells and sub-micron to micron-sized agglomerates are more appropriate for phagocytosis by THP-1 than nano-sized agglomerates [28]. Therefore, we speculate that the increased uptake of LA via phagocytosis might account for these distinct responses. However, we did not notice such effects with $117 \mathrm{~nm} \mathrm{TiO}_{2}$, possibly because the size of SA and LA was already optimal for phagocytosis (250 and $500 \mathrm{~nm}$ ) and equally taken up by the cells. This indicates that the agglomeration state of $\mathrm{TiO}_{2}$ influences the biological responses not only depending on the cell type but also depending on the primary particle size. When summing up these in vitro results, we can conclude that, in any case, SA were not biologically more active than LA (Table 4A).

Studies reporting the influence of agglomeration on in vivo toxicity are scarce. Therefore, we exposed mice 


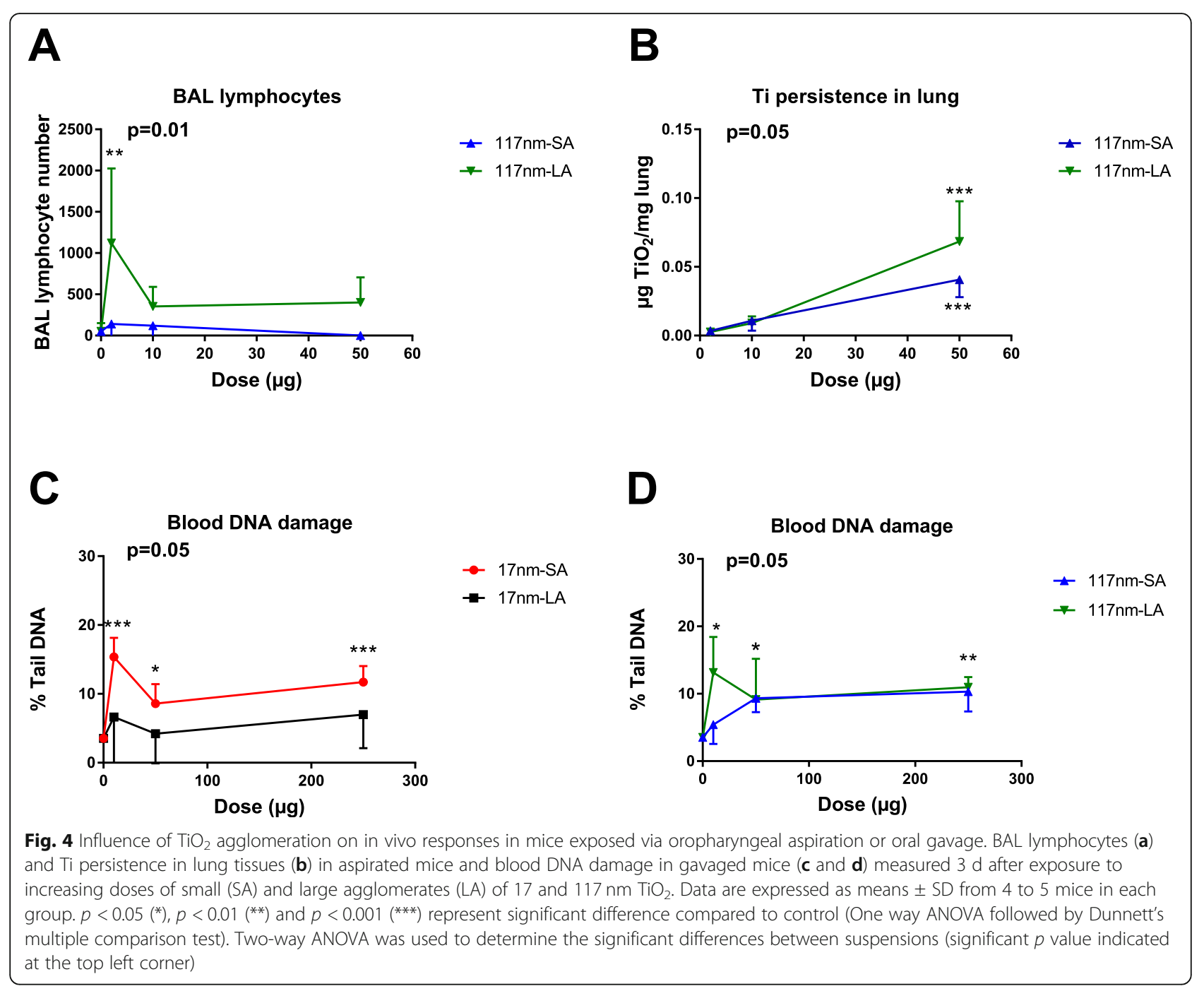

to differently agglomerated $\mathrm{TiO}_{2} \mathrm{NPs}$ via two exposure routes and investigated acute toxic effects. Exposure to LA of $117 \mathrm{~nm} \mathrm{TiO}_{2}$ via aspiration resulted in increased retention of $\mathrm{Ti}$ in the lung and a higher number of BAL lymphocytes compared to the SA. Inhalation studies recorded that large agglomerates of nano- $\mathrm{TiO}_{2}$ induced a stronger pulmonary response in rats than smaller ones $[29,30]$, which is in agreement with our findings. However, such differences were not observed for the $17 \mathrm{~nm}$ $\mathrm{TiO}_{2}$. Noël et al. [30] found that larger agglomerates of $10-30 \mathrm{~nm}$ and $50 \mathrm{~nm}$ sized $\mathrm{TiO}_{2}$ induced stronger pulmonary response than smaller and larger agglomerates of $5 \mathrm{~nm}$ sized $\mathrm{TiO}_{2}$ in a rat inhalation study. Thus, we can conclude that $\mathrm{TiO}_{2}$ agglomeration increases the pulmonary responses but depending on the primary particle size. In contrast, systemic DNA damage was influenced by the agglomeration state of both $\mathrm{TiO}_{2}$ but inversely. These results suggest that the influence of $\mathrm{TiO}_{2}$ agglomeration state on biological responses is not limited to the site of particle deposition, but could also affect systemic responses. Overall, SA did not induce more severe responses compared to LA except in one case (Table 4B).

Size has been identified as a major determinant of NM toxicity and their distribution is an important parameter to classify NMs according the EU definition [31]. To implement regulations and guidance in practice, standardization and validation of methods for measurement of the primary particle and AA characteristics, particularly their size, are essential to examine the effect of agglomeration on toxicity. However, not much attention has been paid to other size characterization, i.e. only reporting the least size detected but not the agglomeration status. DLS and PTA methods measure the hydrodynamic diameter of AA and estimate the AA size such as the diameter of sphere with equivalent hydrodynamic mobility. They do not measure the AA shape. As observed in our study, for particles that are agglomerated, DLS and PTA results are biased towards larger 
values [32]. The combination of TEM imaging and image analysis allows to more reliably analyse the size and shape of primary particles [33] and AA of $\mathrm{TiO}_{2}$ NPs [34]. Therefore, the TEM method was standardized and validated for the examined materials such that the suspensions examined in this study could be clearly differentiated, thus a reliable comparison of toxic/biological responses induced by differently sized agglomerates was possible.

In addition to the size differences between suspensions at the start of the exposure in vitro, evaluation of further agglomeration in cell exposure medium are crucial to determine their influence on toxicity [35-37]. In our study, we noticed significant agglomeration of both $\mathrm{TiO}_{2}$ only in Caco2 cell exposure medium. Cell exposure media with different compositions were shown to influence the stability of $\mathrm{TiO}_{2} \mathrm{NPs}$ [38]. We suspect that the use of $1 \%$ non-essential amino acids (NEAA) in Caco2 cell exposure medium (necessary for the growth of Caco2 cells) might influence further agglomeration over time while such NEAA was absent in HBE or THP-1 cell exposure medium. When comparing epithelial cell types, i.e.HBE and Caco2, a slight difference in the magnitude of biological responses were observed, but further agglomeration did not lead to different effects as observed in THP-1. In vivo, it is more than likely that the size distribution of the gavaged suspensions is modified by passing through different regions of the digestive tract, where $\mathrm{pH}$ changes depending on the region. However, whether these in vivo modifications can be related to the change in in vitro size distribution in Caco-2 cell exposure medium can hardly be predicted.

Recent studies recognised effective density as a potential factor affecting the sedimentation and in vitro dosimetry (effective dose) [36, 39]. Therefore, we determined the effective density of $\mathrm{TiO}_{2}$ in all suspensions and simulated delivered in vitro doses using a distorted grid (DG) model [40]. The agglomeration state of both $\mathrm{TiO}_{2}$ had only a slight effect on the effective density of $\mathrm{TiO}_{2}$ and delivered doses. Further, the simulated delivered dose was not more than $60 \%$ of the nominal dose applied for all the $\mathrm{TiO}_{2}$ suspensions, indicating that the sedimentation/gravitational settling did not dominate the transport of the $\mathrm{TiO}_{2} \mathrm{NPs}$ regardless of their agglomeration state. Based on these results, we can conclude that, the delivered in vitro doses were not a confounder in assessing the differential in vitro responses observed between LA and SA suspensions.

Each type of $\mathrm{TiO}_{2} \mathrm{NP}$ is characterized by different physico-chemical properties and it exhibits different biological activities [41, 42]. Therefore, the results of this study may only be applicable to the $\mathrm{TiO}_{2}$ examined here. However, the approach and the dispersion methodology developed can be applied to investigate the (differential) toxicity of other types of NMs with regard to their agglomeration status.

\section{Conclusion}

The dispersion protocol and descriptive TEM characterization used in this study allowed to investigate the influence of agglomeration state of $\mathrm{TiO}_{2} \mathrm{NPs}$ on their toxicity/biological responses. According to the nanotoxicity paradigm, we hypothesized that small agglomerates would induce stronger toxicity than larger ones. Somewhat contra intuitively, we noted that, in most cases, no difference was found between agglomeration states and if any difference was found, large agglomerates mostly induced a stronger effect. In in vitro assays, the major differences were found in THP-1 cells, which is of interest in view of differential responses of innate immune cells. Also in in vivo assays, differential responses were noted both after respiratory and oral exposure. Thus, we conclude that agglomeration state of $\mathrm{TiO}_{2} \mathrm{NPs}$ can influence their toxicity and that large agglomerates do not appear less active than small agglomerates. These results are, most probably, material and primary particle size specific, rather than agglomeration specific.

\section{Materials and methods $\mathrm{TiO}_{2} \mathrm{NPs}$}

The European Commission's Joint Research Centre (JRC, Italy) kindly provided the $\mathrm{TiO}_{2}$ representative test materials JRCNM10202a and JRCNM10200a. Mean primary particle sizes (Feret min) determined by TEM are 17 and $117 \mathrm{~nm}$ respectively and a detailed information on these particles is provided in the JRC report [43].

\section{Dispersion of NPs}

A method based on a protocol developed by Guiot and Spalla [22] was used to generate two differently agglomerated suspensions of the same $\mathrm{TiO}_{2} \mathrm{NPs}$. Additional file 1: Figure $\mathrm{S} 1$ shows the changes in zeta potential of $\mathrm{TiO}_{2} \mathrm{NPs}$ as a function of $\mathrm{pH}$. The Zeta potential varies as a function of $\mathrm{pH}$, which in turn determines the electrostatic interaction of particles with other particles and with the surrounding medium. Based on this principle, the agglomeration state over a range of $\mathrm{pH}(2-12)$ was analysed for each particle type using TEM, and $\mathrm{pH}$ conditions at which particles existed in different agglomeration states were selected.

Additional file 1: Figure S2 shows the schematic diagram of the modified Guiot and Spalla protocol to prepare our ad-hoc stock suspensions. After dispersing the particles in the respective $\mathrm{pH}$ solutions, the suspensions were sonicated, delivering $7056 \mathrm{~J}$ with a probe sonicator (Microson XL 2000, $3 \mathrm{~mm}$ probe, Belgium), and stabilized with $0.2 \mu \mathrm{m}$ membrane filtered (Thermofischer Scientific, Belgium) 1\% BSA (Sigma-Aldrich, Belgium). To ensure the delivery of the targeted energy and reproducibility of suspensions, probe sonicator was calorimetrically calibrated using the NANOREG protocol [44]. The 
experiments were repeated on different occasions and the variability of energy delivered between experiments was observed to be less than $10 \%$. After sonication, the suspensions at $\mathrm{pH} 2$ were readjusted to $\mathrm{pH} 7-7.5$ by slowly adding sodium hydroxide solution $(\mathrm{NaOH}) 0.1 \mathrm{M}$. The stock suspensions were $2.56 \mathrm{mg} \mathrm{TiO}_{2} / \mathrm{mL}$ with $0.25 \%$ BSA and at $\mathrm{pH} 7-7.5$, and freshly prepared for each independent experiment.

\section{Dynamic light scattering (DLS)}

DLS measurements were performed with a ZetaSizer Nano ZS instrument (Malvern Instruments, Malvern, $\mathrm{UK})$ to evaluate the size distribution of $\mathrm{TiO}_{2} \mathrm{NP}$ in suspensions. Stock suspensions and $\mathrm{TiO}_{2}$ in cell culture medium $(100 \mu \mathrm{g} / \mathrm{mL})$ were tested for each condition. The settings were 2.4 for the refractive index and 0.2 for the absorption parameter. The selected dispersant was water (refractive index of 1.33). The mean hydrodynamic diameter (Z-average) and the polydispersity index (PDI) were measured with version 7.11 of the Zetasizer software.

\section{Transmission Electron microscopy (TEM)}

TEM specimens of stock suspensions were prepared and examined using a well-aligned Tecnai Spirit microscope (FEI, Eindhoven, Netherlands) operating at $120 \mathrm{kV}$, at a spot size 3 and imaged in BF-mode in parallel beam conditions. Images were typically recorded at approximately $500 \mathrm{~nm}$ below minimal contrast conditions. Digital micrographs were made using the bottommounted $4 \times 4 \mathrm{~K}$ Eagle CCD-camera and converted to tif-format using the TIA software. Equivalent circle (ECD) and Feret minimum diameter (Feret min) analyses were performed as described in [45].

\section{In vitro dosimetry}

Volume Centrifugation Method (VCM) was used to determine the effective density of $\mathrm{TiO}_{2} \mathrm{NPs}$ in cell culture medium (CCM) and the dose delivered to the cells over $24 \mathrm{~h}$ exposure was simulated using a Distorted Grid (DG) model, as described in [40].

\section{Cell culture conditions}

The human bronchial epithelial cell line (16HBE14o- or HBE) and the human monocytic cell line (THP-1) were kindly provided by Dr. Gruenert (University of California, San Francisco, USA), and the Caucasian colon adenocarcinoma cell line (Caco2) (P.Nr: 86010202) was purchased from Sigma-Aldrich (Belgium). HBE cells were cultured in DMEM/F12 supplemented with 5\% FBS, $1 \%$ penicillinstreptomycin (P-S) $(100 \mathrm{U} / \mathrm{mL}), 1 \%$ L-glutamine $(2 \mathrm{mM})$ and $1 \%$ fungizone $(2.5 \mathrm{~g} / \mathrm{mL})$ while RPMI 1640 supplemented with $10 \%$ FBS, $1 \%$ P-S $(100 \mathrm{U} / \mathrm{mL}), 1 \%$ Lglutamine $(2 \mathrm{mM})$ and $1 \%$ fungizone $(2.5 \mathrm{~g} / \mathrm{mL})$ was used for THP-1. DMEM/HG supplemented with 10\% FBS, 1\% P-S $(100 \mathrm{U} / \mathrm{mL}), 1 \%$ L-glutamine $(2 \mathrm{mM}), 1 \%$ fungizone $(2.5 \mathrm{~g} / \mathrm{mL})$ and $1 \%$ non-essential amino acids (NEAA) was used for Caco2 cells. All cell culture supplements were purchased from Invitrogen (Belgium) unless otherwise stated. Cells were cultured in T75 flasks (FALCON, USA) at $37^{\circ} \mathrm{C}$ in a $100 \%$ humidified air containing $5 \% \mathrm{CO}_{2}$. Medium was changed every 2 or 3 days and cells were passaged every week ( 7 days). Cells from passage 4 to 10 were used for the experiments.

\section{Exposure conditions in vitro}

We used serum-free exposure media (culture medium without FBS) for in vitro conditions to avoid the influence of serum proteins on particle characteristics and biological responses. For all experiments except TEER measurement, HBE, Caco2 and THP-1 cells were seeded at a density of $1.5 \times 10^{5}, 1.05 \times 10^{5} \mathrm{~cm}^{2}$ (surface area of culture well) and $3.3 \times 10^{5} / \mathrm{mL}$ in 96 or 24 well plates (greiner bio-one, Belgium) and incubated overnight. On the day of exposure, freshly prepared stock suspensions were diluted in BSA $0.25 \%$ to prepare the sub-stocks of different concentrations (40 to $2560 \mu \mathrm{g} / \mathrm{mL}$ ) and further diluted 10 times in serum-free exposure media to achieve the final exposure concentrations (4 to $256 \mu \mathrm{g} /$ $\mathrm{mL}$ ). BSA $0.25 \%$ diluted 10 times in exposure media served as negative control. Cells were then washed with HBSS (without $\mathrm{Ca}^{2+} / \mathrm{Mg}^{2+}$ ) once and exposed to $\mathrm{TiO}_{2}$ NPs. After $24 \mathrm{~h}$, cell cultures were washed twice with HBSS and the respective assays were performed.

\section{Animals and treatments}

Female C57BL/6JRj mice were purchased from Janvier Labs (St Bertevin, France). Eight-week-old animals were kept with sterile rodent feed and acidified water, and housed in positive-pressure air-conditioned units $\left(25^{\circ} \mathrm{C}\right.$, $50 \%$ relative humidity) on a $12 \mathrm{~h}$ light/dark cycle. For aspiration, mice were anaesthesized with a mix of Nimatek, $1 \mathrm{mg} /$ mouse (Eurovet, Bladel, Netherlands) and Rompun, $0.2 \mathrm{mg} / \mathrm{mouse}$ (Bayer, Kiel, Germany) given intraperitoneally, and administered a $50 \mu \mathrm{l}$ suspension of particles or suspension medium at pH7.5 (controls) by oropharyngeal aspiration. For gavage, mice were administered $200 \mu \mathrm{L}$ suspension or dispersion medium. Mice were sacrificed $3 \mathrm{~d}$ after particle administration with an intraperitoneal injection of $12 \mathrm{mg}$ sodium pentobarbital (Certa, Braine-l'Alleud, Belgium).

\section{Blood, broncho-alveolar lavage and organ sampling}

Blood was collected in EDTA tubes for inductively coupled plasma-mass spectrometry (ICP-MS), hematology and genotoxicity (comet assay). Broncho-alveolar lavage (BAL) was performed in mice treated by oro-pharyngeal aspiration cannulating the trachea and infusing the lungs with 
$1 \mathrm{ml} \mathrm{NaCl} 0.9 \%$. Whole lungs were then perfused with $\mathrm{NaCl} 0.9 \%$ and excised. Left lobes were placed in 3.65\% paraformaldehyde (Sigma-Aldrich, St Louis, Missouri, USA) in phosphate buffered saline (PBS) for later histological analysis, and right lobes were used for ICP-MS, and total glutathione $(\mathrm{GSH})$ measurements. BAL were centrifuged $10 \mathrm{~min}$ at $4{ }^{\circ} \mathrm{C}(240 \mathrm{~g})$. Cell-free supernatant (BALF) was used for biochemical measurements including lactate dehydrogenase (LDH) activity and total proteins (Cobas 8000, Roche Diagnostics). After resuspension in PBS, total BAL cells were counted in Turch (crystal violet 1\%, acetic acid 3\%) and cytocentrifuged for differentiation by light microscopy after Diff-Quick staining (200 cells counted, Polysciences, Warrington, UK). Liver, spleen and kidney were collected after gavage for ICP-MS and GSH measurement (liver).

\section{Inductively coupled plasma mass-spectrometry (ICP-MS)}

$200 \mathrm{mg}$ mouse lung tissue were mineralized with $4.5 \mathrm{ml}$ $\mathrm{HNO}_{3} 65 \%$ and $1.5 \mathrm{ml} \mathrm{HCl} \mathrm{30 \%} \mathrm{in} \mathrm{a} \mathrm{microwave} \mathrm{(Multi-}$ wave Go, Anton Paar) before ICP-MS measurement. Ti recovery and the effect of the biological matrix were determined in preliminary experiments (data not shown). Ti was quantified on an ICP-MS Agilent 7500 ce Octopole Reaction System according to the following method: method spectrum, analyte $47 \mathrm{Ti}$, internal standard 74Ge, Helium mode, peak pattern maximum (20), integration time $1 \mathrm{~s}$ per point $/ 20 \mathrm{~s}$ per mass, acquisition time: 5 repetitions. Calibration of the measurement was done with serial dilutions of a TraceCERT Titanium Standard for ICP (soluble Ti).

\section{Cell metabolic activity}

To determine cell metabolic activity, supernatants were removed after $24 \mathrm{~h}$ exposure and cells were incubated with $120 \mu \mathrm{L}$ water soluble tetrazolium salts (WST-1) reagent (Roche, Belgium) diluted in medium without phenol red at the ratio of $1: 10$. After 1 to $2 \mathrm{~h}$ incubation, plates were centrifuged at $1600 \mathrm{~g}$ for $10 \mathrm{~min}, 100 \mu \mathrm{L}$ was transferred to a new plate and the optical density (OD) was recorded using a micro-plate reader (Bio-Rad, USA) at $450 \mathrm{~nm}$. After subtracting the blank OD values from the sample OD values, results were expressed as percentage of control (untreated) cells.

\section{Effect on cell viability}

Cell viability was assessed by cellular leakage of LDH using a kinetic assay [46]. At the end of exposure, supernatants were transferred to a new plate and cells were incubated with triton $0.2 \%$ (Sigma-Aldrich, Belgium). After $30 \mathrm{~min}$, plates were centrifuged at $1600 \mathrm{~g}$ for $10 \mathrm{~min}$. After transfer to a new plate, freshly prepared substrate solution (pyruvate+NADH) was added and the absorbance was measured by a spectrophotometer at $340 \mathrm{~nm}$ for $3 \mathrm{~min}$ with $15 \mathrm{~s}$ interval. Slope was calculated according to the standard curve. Cell viability was calculated as

[slope of leakage/(slope of lysate + slope of leakage) $* 100$ ] and relative viability as(sample viability/untreated control viability) $* 100$

\section{Total glutathione measurements}

Total glutathione (GSH) is a cellular antioxidant, which is depleted when excessive reactive oxygen species (ROS) are produced. Therefore, GSH depletion was measured as an indicator of oxidative stress induction [47] using a GSH detection kit (Enzo life sciences, Belgium). After $24 \mathrm{~h}$ exposure, cell cultures were washed and harvested using trypsin $0.1 \%$ (Gibco, Belgium). For in vivo, a part of the lung and liver was sliced and weighted. Then, cells/tissues were resuspended in metaphosphoric acid 5\% and homogenized using an ultra turrax t25 tissue homogenizer (Janke \& kunkel, Germany). GSH was quantified according to manufacturer's protocol and the protein content of cell cultures was assessed using bicinchoninic acid (BCA) protein assay kit (Thermo Fischer Scientific, Pierce, Belgium). GSH was normalized to the total protein content in vitro and the results were expressed as percentage of control (untreated) cells. For in vivo, GSH was normalized to the mass of lung or liver tissue. Cells treated with TertButylhydroquinone (t-BHQ) $100 \mu \mathrm{M}$ for $24 \mathrm{~h}$ were used as positive control (data not shown).

\section{Cytokine quantification}

As indicators of pro-inflammatory responses, interleukins (IL) - 8 , IL-6, IL- $1 \beta$ and tumor necrosis factor-alpha $(\mathrm{TNF}-\alpha)$ levels were measured using enzyme-linked immunosorbent assay (ELISA) kits (Sigma-Aldrich, Belgium) in cell supernatants according to manufacturer's protocol. Results were normalized to the total protein content and expressed as a ratio to control (untreated) cells. Cells treated with LPS $1 \mu \mathrm{g} / \mathrm{mL}$ for $24 \mathrm{~h}$ were used as positive control (data not shown).

\section{Trans-epithelial electrical resistance}

Trans-epithelial electrical resistance (TEER) was measured in epithelial (HBE and Caco2) monolayers as an estimation of epithelial barrier integrity. HBE and Caco2 cells were seeded at a density of $2 \times 10^{4}$ cells per well in 24 well transwell inserts $(0.4 \mu \mathrm{m}$ pore size, polyester membrane, Corning, CLS3470 Sigma). TEER was monitored everyday using a Chopstick electrode and an epithelial voltohmmeter (EVOM) (World Precision Instruments, Sarasota, USA). After 7 days, cultures with TEER $>600 \Omega . \mathrm{cm}^{2}$ were exposed to different concentrations of $\mathrm{TiO}_{2}$ suspensions for $24 \mathrm{~h}$ and TEER was measured. Cultures exposed to sodium dodecyl sulfate (SDS) $200 \mu \mathrm{g} / \mathrm{mL}$ for $24 \mathrm{~h}$ served as positive control for epithelial barrier disruption (data not shown). Results are expressed as percentage of control (untreated) cells. 


\section{Comet assay}

In earlier studies, cellular and in some cases nuclear uptake of $\mathrm{TiO}_{2}$ has been shown [48-51]. In our study, we verified cellular internalization in $\mathrm{HBE}$ cells (Additional file 1: Figure S9). DNA strand breaks were quantified as a measure of DNA damage. Cell cultures exposed to noncytotoxic NM concentrations $(5,25,50$ and $100 \mu \mathrm{g} / \mathrm{mL}$ ) were used to quantify DNA strand breaks using alkaline comet assay kit (Trevigen, C.No.4250-050-K) according to manufacturer's protocol. Cells treated with methyl methane sulfonate (MMS, Sigma-Aldrich, Belgium) $100 \mu \mathrm{M}$ for $1-2 \mathrm{~h}$ served as positive control. For in vivo experiments, comet assay was performed on blood and BAL cells collected from animals. Untreated animal blood or BAL cells exposed to $\mathrm{H}_{2} \mathrm{O}_{2} 100 \mu \mathrm{M}$ for 15 min served as positive control. Slides were imaged using microscopy (BX61, Olympus, Belgium) in FITC mode and at 10x magnification. Casplab software version casplab_1.2.3beta2 (http:// casplab.com/download) was used to score 50 comets per well. The mean percentage of tail DNA was calculated from the median of three independent experiments.

\section{Statistical analysis}

For in vitro assays, three independent experiments were performed in triplicate or duplicate and data was presented as mean \pm standard deviation (SD). For in vivo, mean \pm SD was calculated for 4-5 animals per group. Using GraphPad prism 7 software (https://www.graphpad.com/), results were analysed with one-way ANOVA followed by a Dunnett's multiple comparison test to determine the significance of differences compared with control. Two-way ANOVA followed by Bonferroni's multiple comparison test was used to determine significance of differences between suspensions (see Table 4 for explanation).

\section{Supplementary information}

Supplementary information accompanies this paper at https://doi.org/10. 1186/s12989-020-00341-7.

Additional file $\mathbf{1}$ : Table $\mathbf{S 1}$. Main parameters necessary to calculate the delivered dose in vitro for different the $\mathrm{TiO}_{2}$ suspensions. Figure S1. $\mathrm{pH}$ vs Zeta potential curves. $17 \mathrm{~nm} \mathrm{TiO}_{2}$ (A) and $117 \mathrm{~nm} \mathrm{TiO}$ (B). Figure S2. Scheme of the protocol for the preparation of $\mathrm{SA}$ and $\mathrm{LA}$ from $\mathrm{TiO}_{2}$ suspensions. To obtain small (SA) and large agglomerates (LA), 17 and $117 \mathrm{~nm} \mathrm{TiO}_{2}$ were dispersed at different $\mathrm{pH}$ conditions, sonicated and stabilized with BSA $0.25 \%$. The suspensions dispersed at $\mathrm{pH} 2$ were readjusted to $\mathrm{pH} 7-7.5$ using $0.1 \mathrm{M} \mathrm{NaOH}$. Figure $\mathbf{S 3}$. Influence of $\mathrm{TiO}_{2}$ agglomeration on cytotoxicity in vitro. WST-1 and LDH assay were used to measure the cell metabolic activity in $\operatorname{HBE}(\mathrm{A}), \mathrm{Caco} 2(\mathrm{C})$ and THP-1 (E) and cell viability in HBE (B) Caco2 (D) and THP1 (F) after $24 \mathrm{~h}$ exposure to small (SA) and large agglomerates (LA) of $17 \mathrm{~nm}$ and $117 \mathrm{~nm} \mathrm{TiO}_{2}$. Data are expressed as means \pm SD from three independent experiments performed in triplicates. $p<0.001$ (**) $^{* *}$ represents significant difference compared to control (One-way ANOVA followed by Dunnett's multiple comparison test). Figure S4. Influence of $\mathrm{TiO}_{2}$ agglomeration on total glutathione $(\mathrm{GSH})$ in vitro. GSH depletion was measured as an indicator of oxidative stress in $\operatorname{HBE}(A, B)$ and $\mathrm{Caco} 2(C)$ cells after $24 \mathrm{~h}$ exposure to small $(S A)$ and large agglomerates $(L A)$ of $17 \mathrm{~nm}(A, C)$ or $117 \mathrm{~nm} \mathrm{TiO}_{2}(B)$.
Data are expressed as means \pm SD from three independent experiments performed in duplicates. $p<0.05\left({ }^{*}\right), p<0.01\left(^{* *}\right)$ and $p<0.001\left({ }^{* *}\right)$ represent significant difference compared to control (One-way ANOVA followed by Dunnett's multiple comparison test). Figure S5. Influence of $\mathrm{TiO}_{2}$ agglomeration on barrier integrity in epithelial monolayers in vitro. Trans-epithelial electrical resistance (TEER) was measured in $\mathrm{HBE}(\mathrm{A}, \mathrm{B})$ and $\mathrm{CaCO} 2(\mathrm{C})$ after $24 \mathrm{~h}$ exposure to small (SA) and large agglomerates $(\mathrm{LA})$ of $17 \mathrm{~nm}(\mathrm{~A})$ or $117 \mathrm{~nm} \mathrm{TiO}_{2}(\mathrm{~B}, \mathrm{C})$. Data are expressed as means \pm SD from three independent experiments performed in duplicates. $p<$ $0.05\left({ }^{*}\right), p<0.01\left(^{* *}\right)$ and $p<0.001\left(^{* * *}\right)$ represent significant difference compared to control (One-way ANOVA followed by Dunnett's multiple comparison test). Figure S6. Influence of $\mathrm{TiO}_{2}$ agglomeration on cytokine release in vitro. TNF- $\alpha(A), I L-6(B)$ and $I L-\beta(C)$ levels were measured in the supernatant of the HBE $(A, B)$ and THP-1 (C) after $24 \mathrm{~h}$ exposure to small (SA) and large agglomerates (LA) of $17 \mathrm{~nm}(\mathrm{~A}, \mathrm{C})$ or $117 \mathrm{~nm} \mathrm{\textrm {TiO } _ { 2 }}$ (B). Data are expressed as means \pm SD from three independent experiments performed in duplicates. $p<0.05\left(^{*}\right), p<0.01\left(^{* *}\right)$ and $p<0.001$ $\left({ }^{* * *}\right)$ represent significant difference compared to control (One-way ANOVA followed by Dunnett's multiple comparison test). Figure S7. Influence of $\mathrm{TiO}_{2}$ agglomeration on DNA damage in vitro. DNA damage was measured in $\mathrm{HBE}(\mathrm{A}, \mathrm{C}), \mathrm{CacO} 2(\mathrm{~B}, \mathrm{D})$ and THP-1 (E) after $24 \mathrm{~h}$ exposure to small (SA) and large agglomerates (LA) of $17 \mathrm{~nm}(\mathrm{~A}, \mathrm{~B})$ or $117 \mathrm{~nm} \mathrm{TiO}_{2}$ $(C, D, E)$. Data are expressed as means \pm SD from three independent experiments performed in duplicates. $P<0.05\left({ }^{*}\right), p<0.01\left(^{* *}\right)$ and $p<$ $0.001\left(^{* *}\right)$ represent significant difference compared to control (One-way ANOVA followed by Dunnett's multiple comparison test). Figure S8. Influence of $\mathrm{TiO}_{2}$ agglomeration on in vivo toxicity in mice exposed via oropharyngeal aspiration. BAL lymphocytes (A), Ti persistence in lung tissues (B) and BALF LDH activity (C) measured after $3 \mathrm{~d}$ in mice aspirated with different doses of small (SA) and large agglomerates (LA). Data are expressed as means \pm SD from 4 to 5 mice in each group. $p<0.05\left(^{*}\right)$, $\left.p<0.011^{* *}\right)$ and $p<0.001\left(^{* *}\right)$ represent significant difference compared to control (One-way ANOVA followed by Dunnett's multiple comparison test). Figure S9. Intracellular uptake of $\mathrm{TiO}_{2}$ agglomerates by $\mathrm{HBE}$ cell cultures and cellular distribution. TEM images of control cells (A) and exposed to $50 \mu \mathrm{g} / \mathrm{mL}$ of $\mathrm{TiO}_{2} \mathrm{NPs}$ for $24 \mathrm{~h}$ : $17 \mathrm{~nm}-\mathrm{SA}$ (B), $17 \mathrm{~nm}-\mathrm{LA}(\mathrm{C}), 117$ nm-SA (D) and 117 nm-LA (E). N -Nucleus; C-Cytoplasm. Some $\mathrm{TiO}_{2}$ agglomerates close to the nucleus induced arch like structures (indicated in red arrow).

\section{Abbreviations}

AA: Agglomerates and aggregates; ANOVA: Analysis of variance;

BAL: Broncho-alveolar lavage; BALF: BAL fluid; BCA: Bicinchoninic acid, assay; BSA: Bovine serum albumin; CCD: Charge coupled device; CCM: Cell culture medium; DG: Distorted grid; DLS: Dynamic light scattering; ECD: Equivalent circle diameter; EDTA: Ethylenediaminetetraacetic acid; ELISA: Enzyme linked immunosorbent assay; FBS: Fetal bovine serum; Feret min: Minimum feret diameter; GSH: Total glutathione; HBSS: Hank's balanced salt solution; IARC: International agency for research on cancer; ICP-MS: Inductively coupled plasma-mass spectrometry; IL: Interleukin; JRC: Joint research commission; LA: Large agglomerates; LDH: Lactate dehydrogenase; LPS: Lipopolysaccharide; MMS: Methylmethane sulfonate; NMs: Nanomaterials; NPs: Nanoparticles; OD: Optical density; PBS: Phosphate buffer saline; PDI: Polydispersity index; P-S: Penicillin-streptomycin; PTA: Particle tracking analysis; ROS: Reactive oxygen species; SA: Small agglomerates; SD: Standard deviation; TEER: Transepithelial electrical resistance; TEM: Transmission electron microscopy; TNF: Tumor necrosis factor; VCM: Volume centrifugation method; WST-1: Water soluble tetrazolium salts 1; Z-average: Mean hydrodynamic diameter; ZS: Zeta sizer

\section{Acknowledgements}

We would like to thank JRC Nanomaterials Repository, Italy for providing the $\mathrm{TiO}_{2}$ samples.

\section{Authors' contributions}

SM, PH, SV, DL and JM designed the experiments, contributed to data analysis and interpretation. SM wrote the manuscript and PH, SV, DL, JM, JP, NS and LG contributed to the structuring and writing of the manuscript. SM performed all in vitro experimental work and, SV and SM performed in vivo experimental work. JM and FB contributed to dispersion making and 
perfomed most physico-chemical characterization. SM and FB performed DLS characterization in biological exposure medium. SC and SM performed cellular uptake studies. All authors read and approved the manuscript.

\section{Funding}

This work was funded by Belgian Science Policy (BELSPO) program "Belgian Research Action through Interdisciplinary Network (BRAIN-be)" for the project "Towards a toxicologically relevant definition of nanomaterials (To2DeNano)" and EU H2020 project (H2020-NMBP-13-2018 RIA): RiskGONE (Science-based Risk Governance of NanoTechnology) under grant agreement $n^{\circ} 814425$.

\section{Availability of data and materials}

The datasets used and/or analysed during the current study are available from the corresponding author on reasonable request.

\section{Ethics approval and consent to participate}

All animal experiments were approved by the local committee for animal research at the Université catholique de Louvain, Comité d'Ethique pour l'Expérimentation Animale, Secteur des Sciences de la Santé, Brussels, Belgium (No LA1230312).

\section{Consent for publication}

$$
\text { Not applicable. }
$$

\section{Competing interests}

The authors declare that they have no competing interests.

\section{Author details}

'Laboratory of Toxicology, Unit of Environment and Health, Department of Public Health and Primary Care, KU Leuven, 3000 Leuven, Belgium. ${ }^{2}$ Trace Elements and Nanomaterials, Sciensano, 1180 Uccle, Belgium. ${ }^{3}$ National Standards, FPS Economy, 1000 Brussels, Belgium. ${ }^{4}$ Department of Oral Health Sciences, KU Leuven, BIOMAT \& UZ Leuven (University Hospitals Leuven), Dentistry, Kapucijnenvoer 7, 3000 Leuven, Belgium. ${ }^{5}$ Laboratory for Occupational and Environmental Hygiene, Unit of Environment and Health, Department of Public Health and Primary Care, KU Leuven, 3000 Leuven, Belgium. ${ }^{6}$ DEWWE, External Service for Prevention and Protection at work, Interleuvenlaan 58, 3001 Heverlee, Belgium. ${ }^{7}$ Louvain centre for Toxicology and Applied Pharmacology, Institute of Experimental and Clinical Research, Université catholique de Louvain, 1200 Brussels, Belgium.

\section{Received: 23 September 2019 Accepted: 6 February 2020}

\section{Published online: 26 February 2020}

\section{References}

1. Fruijtier-Pölloth C. The safety of nanostructured synthetic amorphous silica (SAS) as a food additive (E 551). Arch Toxicol. 2016;90:2885-916.

2. Debia M, Bakhiyi B, Ostiguy C, Verbeek JH, Brouwer DH, Murashov V. A systematic review of reported exposure to engineered nanomaterials. Ann Occup Hyg. 2016;60:916-35.

3. Mihalache R, Verbeek J, Graczyk H, Murashov V, van Broekhuizen P. Occupational exposure limits for manufactured nanomaterials, a systematic review. Nanotoxicology. 2017;11:7-19 Taylor \& Francis.

4. Kuhlbusch TAJ, Asbach C, Fissan H, Göhler D, Stintz M. Nanoparticle exposure at nanotechnology workplaces: a review. Part Fibre Toxicol. 2011;8:1-18.

5. Potočnik J. Commission recommendation of 18 October 2011 on the definition of nanomaterial (2011/696/EU). Off J Eur Union. 2011;L275:38-40.

6. Walter D. Primary Particles - Agglomerates - Aggregates. Nanomaterials. 2013. https://doi.org/10.1002/9783527673919.ch1

7. Boverhof DR, Bramante CM, Butala JH, Clancy SF, Lafranconi M, West J, et al. Comparative assessment of nanomaterial definitions and safety evaluation considerations. Regul Toxicol Pharmacol. 2015;73:137-50 Academic Press.

8. Bleeker EAJ, de Jong WH, Geertsma RE, Groenewold M, Heugens EHW Koers-Jacquemijns $\mathrm{M}$, et al. Considerations on the EU definition of a nanomaterial: Science to support policy making. Regul Toxicol Pharmacol. Elsevier Inc. 2013:65:119-25.

9. Mitrano DM, Motellier S, Clavaguera S, Nowack B. Review of nanomaterial aging and transformations through the life cycle of nano-enhanced products. Environ Int. 2015;77:132-47 Elsevier Ltd.

10. Bruinink $A$, Wang J, Wick $P$. Effect of particle agglomeration in nanotoxicology. Arch Toxicol. 2015;89:659-75.
11. Tourinho PS, van Gestel CAM, Lofts S, Svendsen C, Soares AMVM, Loureiro S Metal-based nanoparticles in soil: fate, behavior, and effects on soil invertebrates. Environ Toxicol Chem. 2012;31:1679-92.

12. Weir A, Westerhoff P, Fabricius L, Hristovski K, Von Goetz N. Titanium dioxide nanoparticles in food and personal care products. Environ Sci Technol. 2012;46:2242-50.

13. Vance ME, Kuiken T, Vejerano EP, McGinnis SP, Hochella MF, Hull DR. Nanotechnology in the real world: redeveloping the nanomaterial consumer products inventory. Beilstein J Nanotechnol. 2015;6:1769-80.

14. IARC Working Group on the evaluation of carcinogenic risks to humans. IARC monographs 93: carbon black, titanium dioxide, and talc. International Agency for Research on Cancer; 2010.

15. ANSES. OPINION of the French Agency for Food, Environmental and Occupational Health \& Safety on the risks associated with ingestion of the food additive E171 [Internet]. Public Health. 2019. Available from: https:// www.anses.fr/en/system/files/ERCA2019SA0036EN.pdf.

16. Shi H, Magaye $\mathrm{R}$, Castranova $\mathrm{V}$, Zhao J. Titanium dioxide nanoparticles: a review of current toxicological data. Part Fibre Toxicol. 2013;10:15.

17. Chen T, Yan J, Li Y. Genotoxicity of titanium dioxide nanoparticles. J Food Drug Anal. Elsevier. 2014;22:95-104.

18. Napierska D, Thomassen LCJ, Rabolli V, Lison D, Gonzalez L, Kirsch-Volders $M$, et al. Size-dependent cytotoxicity of monodisperse silica nanoparticles in human endothelial cells. Small. 2009:5:846-53.

19. Rahman Q, Lohani M, Dopp E, Pemsel H, Jonas L, Weiss DG, et al. Evidence that ultrafine titanium dioxide induces micronuclei and apoptosis in Syrian hamster embryo fibroblasts. Environ Health Perspect. 2002;110:797-800.

20. Kang $T$, Guan $R$, Chen $X$, Song $Y$, Jiang $H$, Zhao J. In vitro toxicity of differentsized ZnO nanoparticles in Caco-2 cells. Nanoscale Res Lett. 2013:8:1-8.

21. Gliga AR, Skoglund S, Wallinder IO, Fadeel B, Karlsson HL. Size-dependent cytotoxicity of silver nanoparticles in human lung cells: the role of cellular uptake, agglomeration and Ag release. Part Fibre Toxicol. 2014;11:11.

22. Guiot C, Spalla O. Stabilization of TiO2 nanoparticles in complex medium through a pH adjustment protocol. Environ Sci Technol. 2013;47:1057-64.

23. Magdolenova Z, Bilaničová D, Pojana G, Fjellsbø LM, Hudecova A, Hasplova $K$, et al. Impact of agglomeration and different dispersions of titanium dioxide nanoparticles on the human related in vitro cytotoxicity and genotoxicity. J Environ Monit. 2012;14:455.

24. Prasad RY, Wallace K, Daniel KM, Tennant AH, Zucker RM, Strickland J, et al. Effect of treatment media on the agglomeration of titanium dioxide nanoparticles: impact on Genotoxicity, cellular interaction, and cell cycle. ACS Nano. 2013;7:1929-42.

25. Lankoff A, Sandberg WJ, Wegierek-Ciuk A, Lisowska H, Refsnes M, Sartowska $B$, et al. The effect of agglomeration state of silver and titanium dioxide nanoparticles on cellular response of HepG2, A549 and THP-1 cells. Toxicol Lett. 2012;208:197-213.

26. Vranic S, Gosens I, Jacobsen NR, Jensen KA, Bokkers B, Kermanizadeh A, et al. Impact of serum as a dispersion agent for in vitro and in vivo toxicological assessments of TiO2 nanoparticles. Arch Toxicol. 2017;91:353-63.

27. Suttiponparnit K, Jiang J, Sahu M, Suvachittanont S, Charinpanitkul T, Biswas P. Role of surface area, primary particle size, and crystal phase on titanium dioxide nanoparticle dispersion properties. 2010.

28. He C, Hu Y, Yin L, Tang C, Yin C. Effects of particle size and surface charge on cellular uptake and biodistribution of polymeric nanoparticles. Biomaterials. 2010. https://doi.org/10.1016/j.biomaterials.2010.01.065.

29. Noël A, Maghni K, Cloutier Y, Dion C, Wilkinson KJ, Hallé S, et al. Effects of inhaled nano-TiO 2 aerosols showing two distinct agglomeration states on rat lungs. Toxicol Lett Elsevier Ireland Ltd. 2012;214:109-19.

30. Noël A, Charbonneau M, Cloutier Y, Tardif R, Truchon G. Rat pulmonary responses to inhaled nano-TiO2: Effect of primary particle size and agglomeration state. Part Fibre Toxicol. 2013;10:1.

31. Rauscher H, Roebben G, Mech A, Gibson N, Kestens V, Linsinger TPJ, et al. An overview of concepts and terms used in the European Commission's definition of nanomaterial. 2019.

32. Roebben G, Ramirez-Garcia S, Hackley VA, Roesslein M, Klaessig F, Kestens V, et al. Interlaboratory comparison of size and surface charge measurements on nanoparticles prior to biological impact assessment. J Nanopart Res. 2011;13:2675-87.

33. De Temmerman P-J, Lammertyn J, De Ketelaere B, Kestens V, Roebben G, Verleysen $\mathrm{E}$, et al. Measurement uncertainties of size, shape, and surface measurements using transmission electron microscopy of near-monodisperse, near-spherical nanoparticles. J Nanopart Res. Springer Netherlands. 2014;16:2177. 
34. De Temmerman P-J, Verleysen E, Lammertyn J, Mast J. Semi-automatic size measurement of primary particles in aggregated nanomaterials by transmission electron microscopy. Powder Technol. 2014;261:191-200.

35. Cohen JM, Teeguarden JG, Demokritou P. An integrated approach for the in vitro dosimetry of engineered nanomaterials. Part Fibre Toxicol. 2014;11:20.

36. Pal AK, Bello D, Cohen J, Demokritou P. Implications of in vitro dosimetry on toxicological ranking of low aspect ratio engineered nanomaterials. Nanotoxicology. 2015;9:871-85.

37. Albanese A, Chan WCW. Effect of gold nanoparticle aggregation on cell uptake and toxicity. ACS Nano. 2011;5:5478-89.

38. Ji Z, Jin X, George S, Xia T, Meng H, Wang X, et al. Dispersion and stability optimization of $\mathrm{TiO} 2$ nanoparticles in cell culture media. Environ Sci Technol. 2010;44:7309-14.

39. Cohen JM, Deloid M, Demokritou P. A critical review of in vitro dosimetry for engineered nanomaterials. Nanomedicine. 2015:10:3015-32.

40. Deloid GM, Cohen JM, Pyrgiotakis G, Demokritou P. Preparation, characterization, and in vitro dosimetry of dispersed, engineered nanomaterials. Nat Protoc. 2017;12:355-71.

41. Sayes CM, Wahi R, Kurian PA, Liu Y, West JL, Ausman KD, et al. Correlating nanoscale titania structure with toxicity: a cytotoxicity and inflammatory response study with human dermal fibroblasts and human lung epithelial cells. Toxicol Sci. 2006;92:174-85.

42. Yu Q, Wang H, Peng Q, Li Y, Liu Z, Li M. Different toxicity of anatase and rutile $\mathrm{TiO} 2$ nanoparticles on macrophages: involvement of difference in affinity to proteins and phospholipids. J Hazard Mater Elsevier. 2017;335: 125-34.

43. European Commission. JRC NANOMATERIALS REPOSITORY- list of representative nanomaterials [Internet]. 2016. Available from: https://ec. europa.eu/jrc/sites/jrcsh/files/JRCNanomaterialsRepositoryListofRepresentativeNanomaterials-201606.pdf.

44. Jensen K, Pojana G, Bilaničová D. Characterization of manufactured nanomaterials, dispersion, and exposure for toxicological testing; 2014

45. De Temmerman P-J, Van Doren E, Verleysen E, Van der Stede Y, Francisco MAD, Mast J. Quantitative characterization of agglomerates and aggregates of pyrogenic and precipitated amorphous silica nanomaterials by transmission electron microscopy. J Nanobiotechnol. 2012;10:24.

46. Öner D, Moisse M, Ghosh M, Duca RC, Poels K, Luyts K, et al. Epigenetic effects of carbon nanotubes in human monocytic cells. Mutagenesis Narnia. 2017:32:181-91.

47. Gehrke H, Frühmesser A, Pelka J, Esselen M, Hecht LL, Blank H, et al. In vitro toxicity of amorphous silica nanoparticles in human colon carcinoma cells. Nanotoxicology. 2013;7:274-93.

48. Ghosh M, Öner D, Duca RC, Cokic SM, Seys S, Kerkhofs S, et al. Cytogenotoxic and DNA methylation changes induced by different crystal phases of TiO2-np in bronchial epithelial (16-HBE) cells. Mutat Res Fundam Mol Mech Mutagen. 2017;796:1-12.

49. Brun E, Barreau F, Veronesi G, Fayard B, Sorieul S, Chanéac C, et al. Titanium dioxide nanoparticle impact and translocation through ex vivo, in vivo and in vitro gut epithelia. Part Fibre Toxicol. 2014;11:13.

50. Proquin $\mathrm{H}$, Rodríquez-Ibarra C, Moonen CGJ, Urrutia Ortega IM, Briedé JJ, de Kok TM, et al. Titanium dioxide food additive (E171) induces ROS formation and genotoxicity: contribution of micro and nano-sized fractions. Mutagenesis. 2017;32:139-49

51. Hanot-Roy M, Tubeuf E, Guilbert A, Bado-Nilles A, Vigneron P, Trouiller B, et al. Oxidative stress pathways involved in cytotoxicity and genotoxicity of titanium dioxide ( $\mathrm{TiO}^{\mathrm{O}}$ ) nanoparticles on cells constitutive of alveolocapillary barrier in vitro. Toxicol in Vitro. 2016;33:125-35.

\section{Publisher's Note}

Springer Nature remains neutral with regard to jurisdictional claims in published maps and institutional affiliations.

Ready to submit your research? Choose BMC and benefit from:

- fast, convenient online submission

- thorough peer review by experienced researchers in your field

- rapid publication on acceptance

- support for research data, including large and complex data types

- gold Open Access which fosters wider collaboration and increased citations

- maximum visibility for your research: over $100 \mathrm{M}$ website views per year

At BMC, research is always in progress.

Learn more biomedcentral.com/submissions 